\title{
Reconstructing migration phases of meandering channels by means of ground-penetrating radar (GPR): the case of the Obra River, Poland
}

\author{
Marcin Słowik
}

Received: 23 August 2010 / Accepted: 19 August 2011 / Published online: 6 September 2011

(C) The Author(s) 2011. This article is published with open access at Springerlink.com

\begin{abstract}
Purpose The main goal of the study was to compare the potential of conventional and geophysical methods (ground-penetrating radar; GPR) to reconstruct the migration phases of a meandering lowland riverbed: the Obra River in western Poland. The purpose was to verify that the migration phases can be distinguished using the GPR measurement providing near-continuous imaging of alluvial structures and to discuss differences between the spatial extent of the migration phases distinguished using geologic data and GPR surveys.

Materials and methods Historical maps from the eighteenth and the nineteenth century were analyzed to study transformations of the Obra River bed pattern. One hundred twenty tube sample borings were undertaken along five profiles to recognize the floodplain lithology. Granulation coefficients were determined using the method of moments to distinguish lithofacies of the alluvial deposits. The GPR measurement was performed using a georadar MALA ProEx equipped with shielded 100 and $250 \mathrm{MHz}$ antennae. The GPR images were compared to geologic profiles to determine the depth scale and accuracy of the measurements. The depth scale of the GPR images was determined on the basis of the correlation of the radar reflections with the geologic profiles. Ten organic sediment samples were collected to determine the age of the migration phases.
\end{abstract}

Responsible editor: Ramon Batalla

M. Słowik $(\bowtie)$

Department of Geographic and Geologic Sciences,

Adam Mickiewicz University,

ul. Dzięgielowa 27,

61-680 Poznań, Poland

e-mail: slowikgeo@poczta.onet.pl
Results and discussion Point bars with layering of sand deposits, organic sediment fills, erosion surfaces, and gravel beds were distinguished using the $250 \mathrm{MHz}$ antenna. However, some of sedimentary structures (e.g., inserts of fine sands in the organic deposits) were beyond the detection range of the antennae. The glacial/alluvial sediment interface was detected using the $100 \mathrm{MHz}$ antenna which enabled the determination of the thickness of the alluvial fill. Traces of a period of early development of the Obra valley and three migration phases of the Obra River bed were distinguished. The research indicated that the Obra was a meandering river at least 7,000 years before present and that during the last 3,000 years, channel islands were formed within the studied section of the valley. Conclusions The GPR method allowed for the analysis of the spatial variability of alluvial deposits and helped to describe how meander bends were formed. The presented GPR images illustrate the spatial extent of the migration phases in a more detailed way than using only sedimentary information. However, geologic data are necessary for interpretation of the GPR images. It was shown that the GPR method gives useful results in spite of rough land surface and dense vegetation.

Keywords Alluvial deposits · Ground-penetrating radar (GPR) method · Lithofacies · Obra River

\section{Introduction}

An analysis of erosion and accumulation processes influencing migration of meander bends is a complex research problem. Such research is usually based on borehole data. This requires great effort and costs and is affected by the discontinuous nature of the data due to the complexity of 
alluvial fills. According to Lunt et al. (2004), describing deposits in three dimensions below the water table and studying depositional processes during the all-important high-flow stages and over large time and space scales are the most important challenges. According to Bersezio et al. (2007), the models based on the borehole data are often oversimplified. Lunt et al. (2004) reported that most of the direct observations of river deposits come from trenches and cut-bank exposures situated above the water table, which represent a small fraction of channel-belt deposits.

The ground-penetrating radar (GPR) method is a geophysical remote-sensing technique that enables the user to analyze the structures of deposits. The achieved resolution depends on a signal frequency. GPR detects electrical discontinuities in the shallow subsurface $(<50 \mathrm{~m})$ by generation, transmission, propagation, reflection, and reception of discrete pulses of high-frequency electromagnetic wave (Neal 2004). Contrasts in the dielectric constant usually cause strong reflections from lithologic boundaries in the subsurface (Jol and Smith 1995). The reflected signal is recorded by a receiver antenna. The depth of the GPR survey is also dependent on the antenna frequency. In general, the higher the antenna frequency, the shallower the depth of penetration is (Neal 2004). Boll et al. (1996) indicated the importance of climate conditions (especially of precipitation and evapotranspiration) on moisture content of soils and effectiveness of the GPR measurements. There are many other factors that can disturb the GPR imaging and limit the depth range of measurements (e.g., rough surface of the studied area, dense vegetation cover, surface and subsurface infrastructure; Bano et al. 2000; Neal 2004). Electrical inhomogeneities are usually caused by water content, dissolved minerals, and clay content in the studied deposits (Wright 1984 in Ekes and Hickin 2001). In the case of alluvial deposits, the diffractions caused by a lateral truncation of various heterogeneities can disturb the image of alluvial structures (Vanderberghe and van Overmeeren 1999). It should be noted that silt or clay deposits cause attenuation of the radar signal which limits the depth range of measurement but can also be useful to determine the thickness of the alluvial fill as was done by Leclerc and Hickin (1997) and Froese et al. (2005). Basal till significantly limits the depth range of the GPR measurements. According to van Heteren (1998), the sediments with high amount of clay attenuate the electromagnetic energy signal, preventing it from penetrating deeper sedimentary units.

The data interpretation is the most challenging component of the GPR work. It is dependent on the availability of reliable subsurface information such as accurate outcrop and borehole information (Ekes and Hickin 2001). Vanderberghe and van Overmeeren (1999) distinguished different types of meandering, braided, and transitional riverbed deposits on the basis of the GPR measurements. Gourry et al. (2003) tried to reconstruct fluvial dynamics of the Loire River. They determined the spatial extent of four "sedimentary bodies" on the basis of electrical soundings and the GPR analysis. The main factor was different conductivity of particular units of the alluvial deposits (Gourry et al. 2003). Garcin et al. (1999 in Gourry et al. 2003) described 10 migration stages of meander bends and each of the phases showed frontal erosion of the concave bank. Kostic and Aigner (2007) distinguished two units of alluvial deposits of a meandering river on the basis of the sedimentological and GPR surveys. Hickin et al. (2009) combined the sedimentological, the GPR, and the capacitively coupled resistivity method to investigate $3 \mathrm{D}$ floodplain architecture and determined the connections between the radar facies, the distribution of resistivity values, and the grain size and sorting of alluvial deposits (Hickin et al. 2009). Ekes and Hickin (2001) noted that particular units of sediments are distinguishable using the GPR method if their conductivity is sufficiently different from adjacent deposits. The deposits should also be situated within the range of a transmitter antenna. Furthermore, various types of alluvial deposit structures are recorded as georadar reflections called "radar stratigraphy" (Jol and Smith 1995 in Vanderberghe and van Overmeeren 1999). Such stratigraphy is used to recognize "radar facies" and to correlate them with the depositional environment. Leclerc and Hickin (1997) and Ekes and Hickin (2001) distinguished the radar facies on the basis of the reflection continuity shape, amplitude, and configuration of the internal reflection. Hickin et al. (2009) presented three dimensional radar facies patterns as connections between different $2 \mathrm{D}$ radar facies.

The main goal of this study is to compare the potential of conventional and geophysical methods to trace the migration phases of a meandering lowland riverbed: the Obra River, in Western Poland. Moreover, the paper highlights a high preservation potential of the river valleys formed in glacial deposits. The first phase of fieldwork was conducted in this area by Słowik (2007) on the lithologic variability of the alluvial deposits by coring and the determination of radiocarbon ages. As a result of these surveys, the migration phases of meander bends were distinguished. The present paper is a continuation of this research and contains the new data on the GPR surveys performed with two frequencies antennae in the rough land surface conditions and additional radiocarbon data. The geophysical (GPR) measurements also allowed the determination of the spatial extent of particular migration phases. It was then possible to compare the migration phases distinguished using conventional methods (Słowik 2007) and the noninvasive geophysical technique. Detailed sedimentary information presented by Słowik (2007) was compared to the GPR data to determine the depth range and to correlate the GPR reflections with the depositional environment. The 
purpose was to verify that the migration phases can be reconstructed using the geophysical measurements.

It should be noted that the geophysical surveys were conducted using two different frequencies antennae, which enabled the comparison of the resolution and the depth penetration of the measurements. Furthermore, an attempt was made to analyze the resolution of the GPR images measured along the profiles featured with different land surface configuration and vegetation cover. Leclerc and Hickin (1997) and Belina et al. (2009) presented the examples of measurements done on topographically even profiles. Here, the GPR surveys were conducted along the profile lines situated in the area with uneven land surface configuration and dense vegetation cover. It was decided that such difficult conditions may be a good example to study the degree of disturbing the picture of alluvial structures in the GPR images. In the present study, attenuation of the GPR signal by basal till was used as an indicator of the contact between the bottom of the alluvial fill and the glacial deposits.

The results are discussed taking into account the mechanisms of the erosion and accumulation processes influencing the migration of the meander bends and the preservation potential of a lowland river valley formed in glacial deposits. Future perspectives for sedimentologic applications of the GPR method are also presented.

\section{Study area}

\subsection{The lower course of the Obra River}

The Obra River flows through the middle and the western part of Poland (Fig. 1) and has a drainage area of $4,022 \mathrm{~km}^{2}$. The river is situated in the area formed by the Vistulian glaciation 15,000-20,000 years ago. The lower course of the Obra valley is formed in fluvioglacial and glacial deposits. Near the town of Międzyrzecz, the river flows through three stagnant water basins (Bartkowski 1956). The lower course of the river has a meandering channel pattern. The only tributary of the Obra River in its lower course is the Paklica River. This is a small water course entering the Obra at Międzyrzecz. The hydrological regime of the Obra River is influenced by the presence of lakes (see Fig. 1), which smooth the amplitude of water stages, discharges, and floods. According to Dynowska (1972), this water regime is considered as a temperate regime, with spring flood and groundwater-rainfall water supply. Maximum discharges occur in spring months (March-April) and exceed $10 \mathrm{~m}^{3} \mathrm{~s}^{-1}$. The highest water level measured during the last 40 years at the Międzyrzecz gauging station reached $340 \mathrm{~cm}$ (Młynarczyk and Słowik 2008). The highest recorded water level caused inundation of almost the entire floodplain area (Młynarczyk and

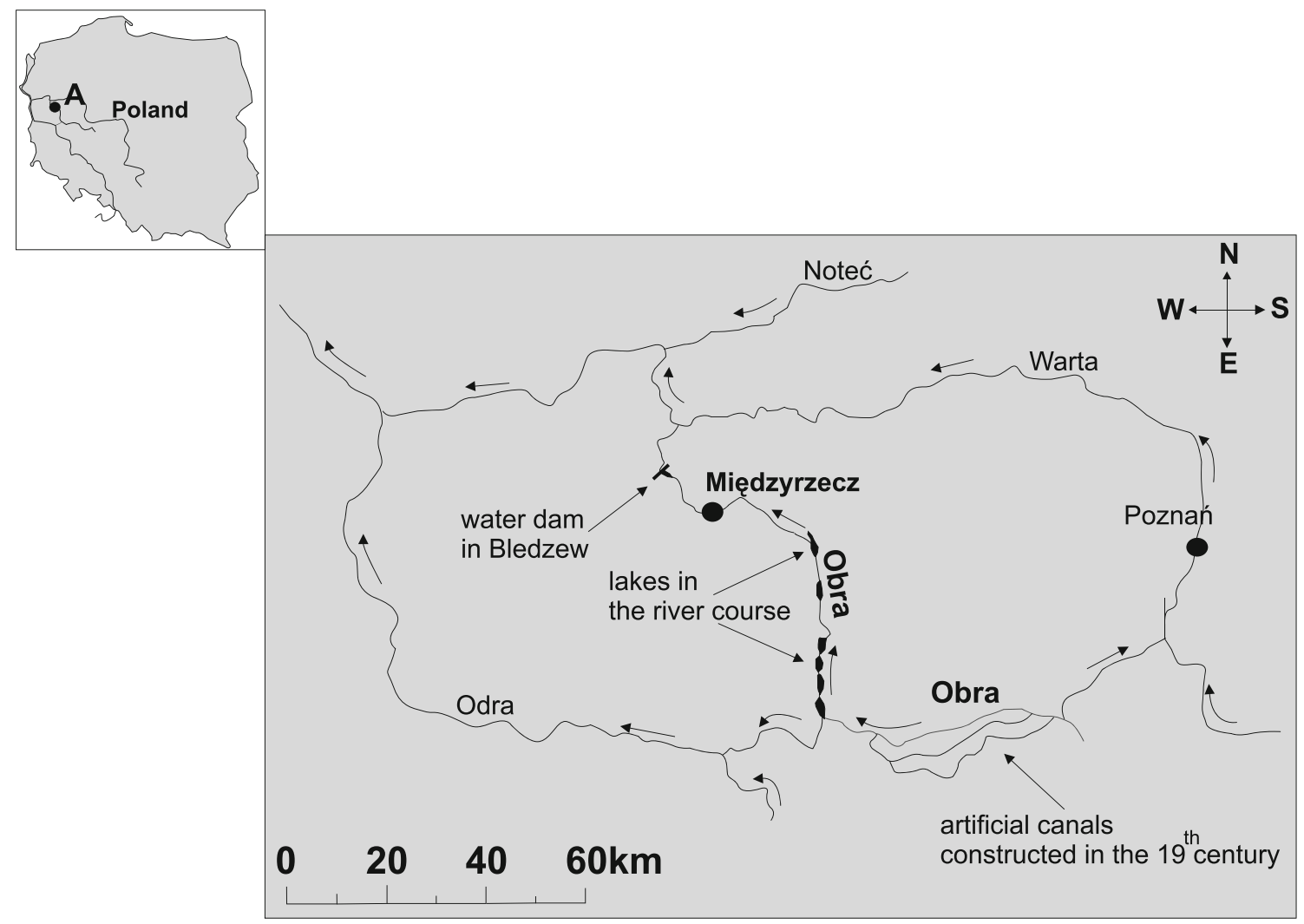

Fig. 1 The Obra River, Poland, in its middle and lower course. A Międzyrzecz 
Słowik 2008), however, no significant change of the river course (e.g., meander cutoffs) was reported after this flood event (hydrological year 1981). Minimum discharges (approximately $2 \mathrm{~m}^{3} \mathrm{~s}^{-1}$ ) usually appear in July and August. The mean annual discharge is $4 \mathrm{~m}^{3} \mathrm{~s}^{-1}$. The groundwater level within the valley floor varies from 0 to $1 \mathrm{~m}$ below the land surface (bls) at low water levels (Słowik et al. 2009).

It should also be noted that the Obra River bed was the site of intensive hydro-engineering works. Three artificial canals (see Fig. 1) were constructed in the middle course of the river in the beginning of the nineteenth century (Slowik 2011). Numerous cutoffs of meander bends have been found in its lower course. However, no direct evidence for anthropogenic intervention was found there (Słowik 2011). Moreover, a water dam was built near the village of Bledzew in the years 1906-1911 (see Fig. 1) and, as a result, an artificial water reservoir was formed there.

\subsection{Research area}

The valley section $3 \mathrm{~km}$ downstream of Międzyrzecz was selected for detailed study because the hydrotechnical works were limited there and they had little influence on the riverbed geometry. The section is illustrated by the archival maps from the nineteenth and the nineteenth century (Fig. 2). The detailed study site is situated $80 \mathrm{~km}$ downstream from the artificial Obra Canals and $20 \mathrm{~km}$ upstream from the water dam in Bledzew (see Fig. 1). Furthermore, geologic surveys conducted by Słowik (2007) in this area provided a good base for the correlation of the GPR signal with the core data. The studied section of the valley has a planimetric area of $0.25 \mathrm{~km}^{2}$ (Fig. 3). Distinct meander bends were formed here (see Fig. 3). The width of the modern riverbed ranges from 20 to $30 \mathrm{~m}$. At water levels close to the bankfull stage, the depth of the riverbed is $2.8 \mathrm{~m}$ (Młynarczyk and Słowik 2008). The valley is deep and narrow; concave banks are steep and high (7-10 m above the valley floor). The surface of the floodplain is flat with slight, elongated depressions. The point bars near the modern riverbed are well marked in the surface of the floodplain. The valley is covered with dense vegetation (mainly alders and hazels with rich undergrowth); the area with relatively better access is situated near profile 3 (see Fig. 3). The studied section of the Obra River valley was shaped in the basal till originating from the Vistulian glaciation and fluvioglacial fine sands deposited by proglacial meltout waters (Słowik 2007). The studies done by Słowik (2007) and Młynarczyk and Słowik (2008) noted that the basal till and armoring of the riverbed condition the thickness of the alluvial sediments. Słowik (2007) found that the maximum thickness of the alluvial fill reaches $5.2 \mathrm{~m}$.
The lithology of the studied area was analyzed by Słowik (2007). The thickness of the alluvial deposits reaches $5.2 \mathrm{~m}$ in profile 1 and $3.8 \mathrm{~m}$ in profile 3 . The bottom of the alluvial fill is formed by coarse and medium sands. The sediments are poorly sorted (standard deviation, 1.5-2.0). Fine sands were deposited above the lag sediments with a mean diameter of 2.1-2.8 $\Phi$. Fills of organic deposits (peats and gyttjas) alternate with sand bars. The maximum thickness of the organic deposits reaches $3 \mathrm{~m}$. Some of the organic sediments contain inserts of fine sands (mean diameter $=2.5-2.8 \Phi$ ). Sandy silts and fine sands with organic matter form the top part of the studied profiles (Słowik 2007). Six lithofacies of the Obra valley alluvial deposits were distinguished on the basis of the granulation coefficients (mean diameter, standard deviation, kurtosis, and skewness) calculated using the method of moments (Fig. 4; Słowik 2007). The names of the lithofacies (see caption of Fig. 4) and the procedure of their determination was based on the study by Rotnicki and Młynarczyk (1989) regarding the Prosna River alluvial deposits. The Obra River lithofacies represent finer deposits in comparison with other lowland rivers (e.g., the Prosna River; Rotnicki and Młynarczyk 1989), especially in the case of the lag deposits, the bottom part of point bar, and the lower segment of middle part of point bar lithofacies. The main reason is the intensity of erosion and accumulation processes and the sort of material available to be transport to the Obra River bed. Moreover, there are substantial differences in the discharges of the Obra (about $8 \mathrm{~m}^{3} \mathrm{~s}^{-1}$ ) and the Prosna River $\left(22.5 \mathrm{~m}^{3} \mathrm{~s}^{-1}\right.$; Rotnicki and Młynarczyk 1989), which influence the conditions of sediment transport and erosion/deposition intensity during flood events supplying lag deposits with admixtures of coarse material (Rotnicki and Młynarczyk 1989).

\section{Materials and methods}

The GPR measurement was conducted along three geologic profiles (see Fig. 3) to study the structure of alluvial deposits and to trace the migration phases of the Obra River bed. The measurement was done using a MALA ProEx georadar equipped with shielded 100 and $250 \mathrm{MHz}$ antennae to compare the resolution and the depth range of the GPR surveys. The depths of penetration ranged from 3.0 to $4.7 \mathrm{~m} \mathrm{bls}$ ( $250 \mathrm{MHz}$ antenna) and from 8.2 to $8.5 \mathrm{~m}$ bls (100 MHz antenna). Using the antennae of two different frequencies enabled the determination of the thickness of the Obra valley alluvial fill and to study the details of its architecture. A lower frequency antennae (e.g., $50 \mathrm{MHz}$ ) would allow greater depth penetration, however, the thickness of individual sediment units is below its resolution (Ekes and Hickin 2001). The measurement was 
Fig. 2 Topographic maps of the study area from 1750,1828 , and 1894 illustrating meander bends within and in the vicinity of the detailed research area (source of the maps: Berlin Staatsbibliothek). The town of Miedzyrzecz is called "Meseritz" here. The names "Kirchsdorf" and "Georgsdorf" refer to the same village. The detailed research area is marked on the maps with a white rectangle

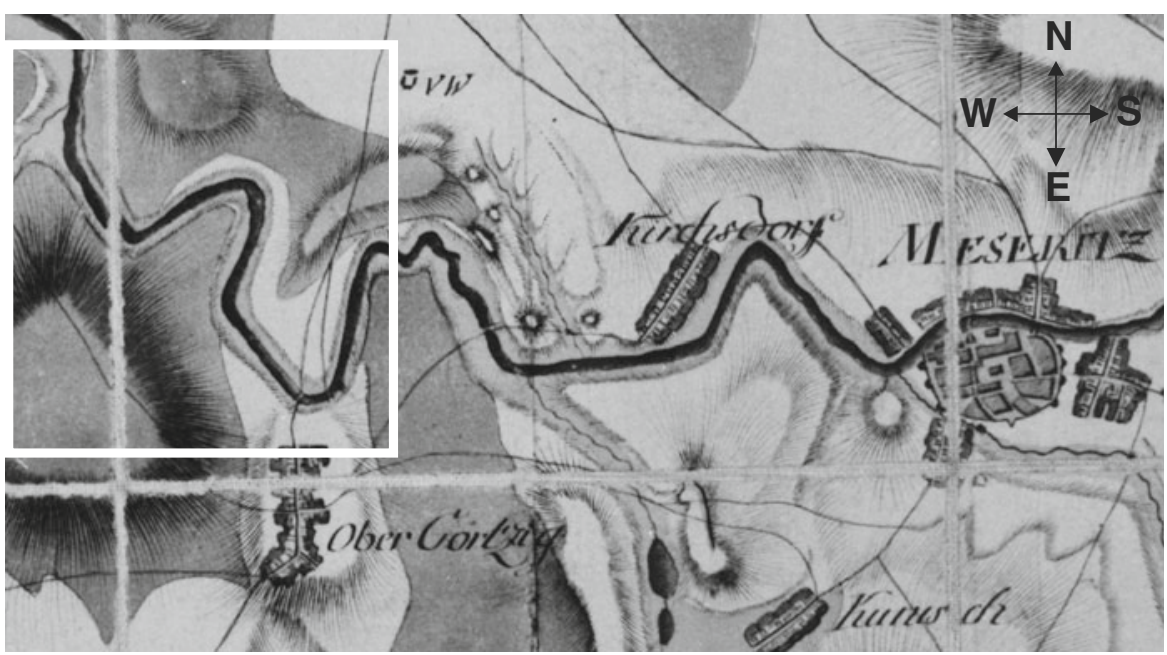

1750

scale unknown
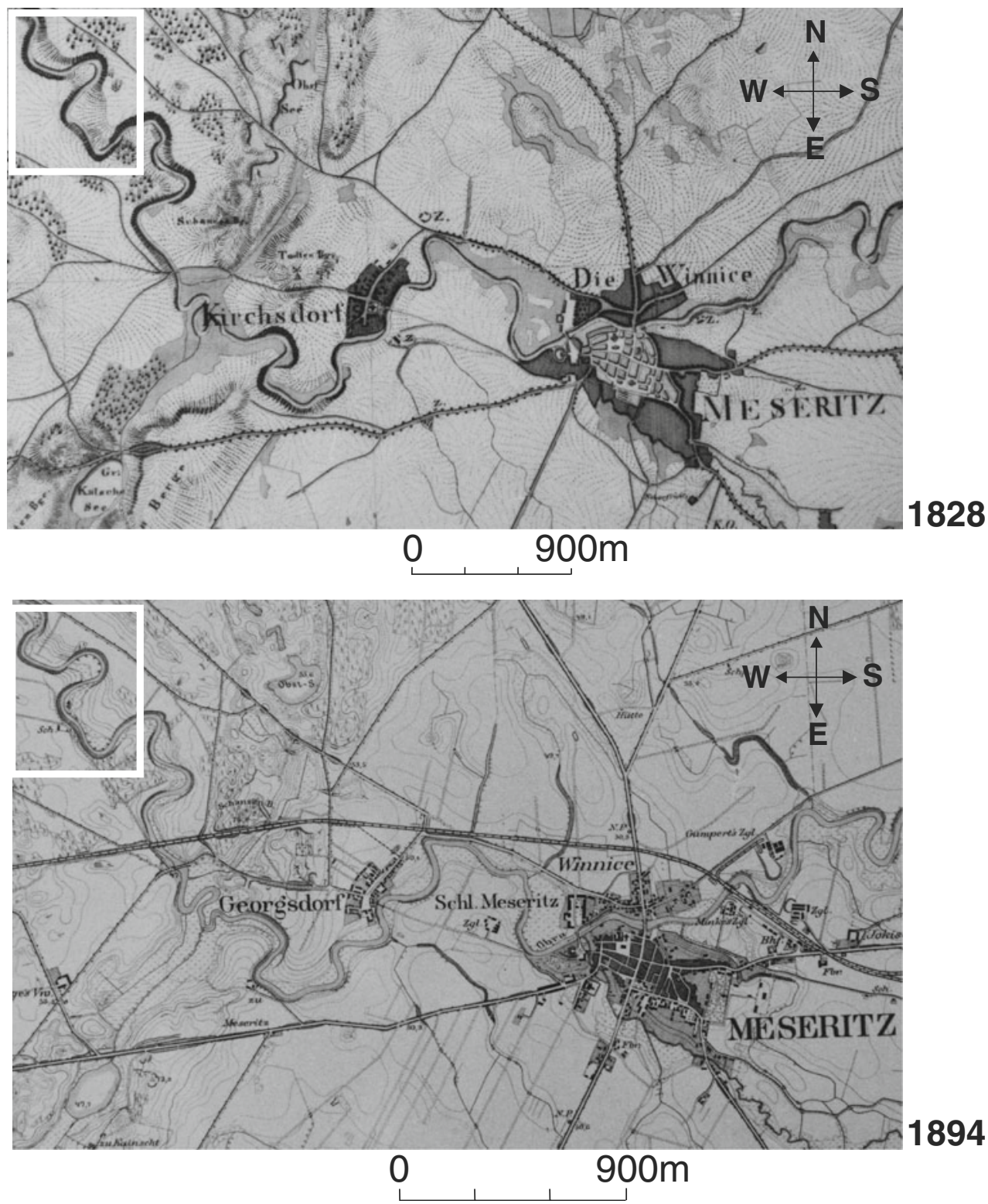
Fig. 3 Detailed research area; 1 geologic profiles, 2 the GPR measurement profiles

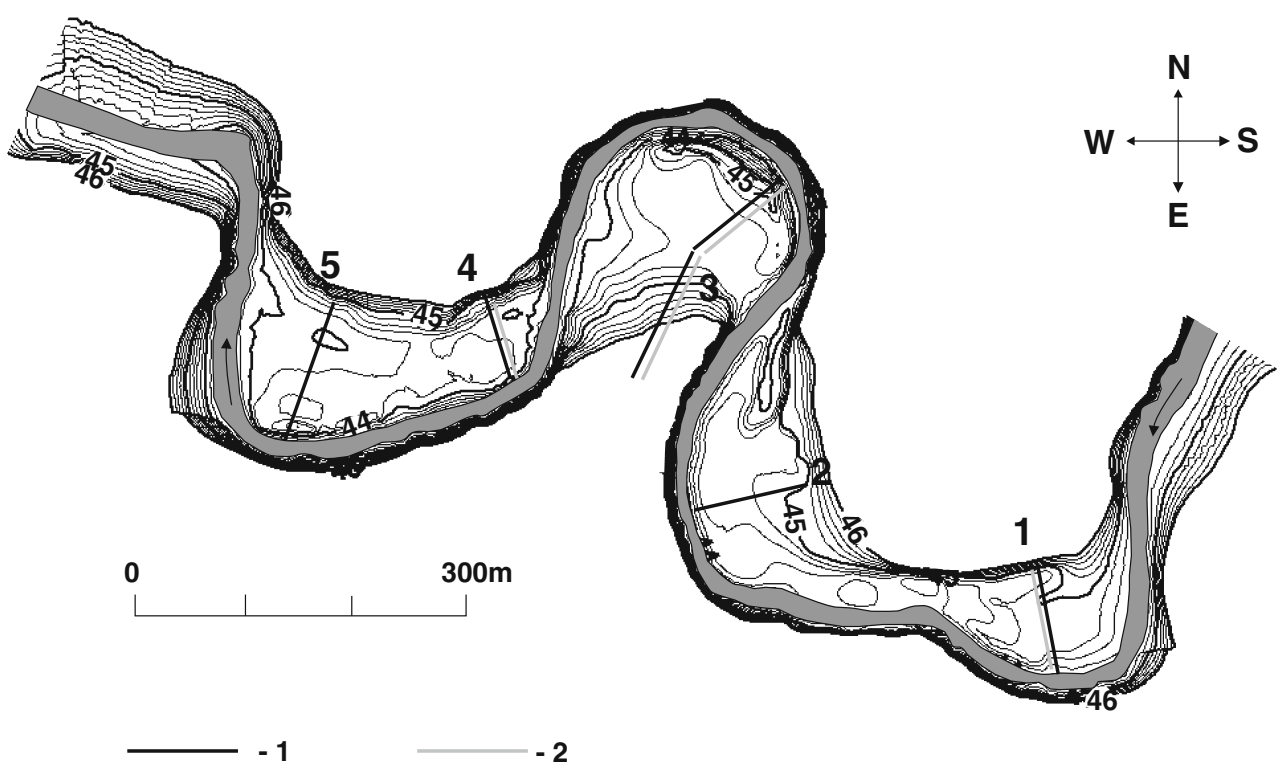

triggered at constant spacings $(0.099 \mathrm{~m}$; Table 1$)$ by an odometer wheel. The parameter settings used are presented in Table 1.

It should be noted that profiles 1 and 4 were situated within the valley section where the land surface was rough and covered with dense vegetation. For this reason, the
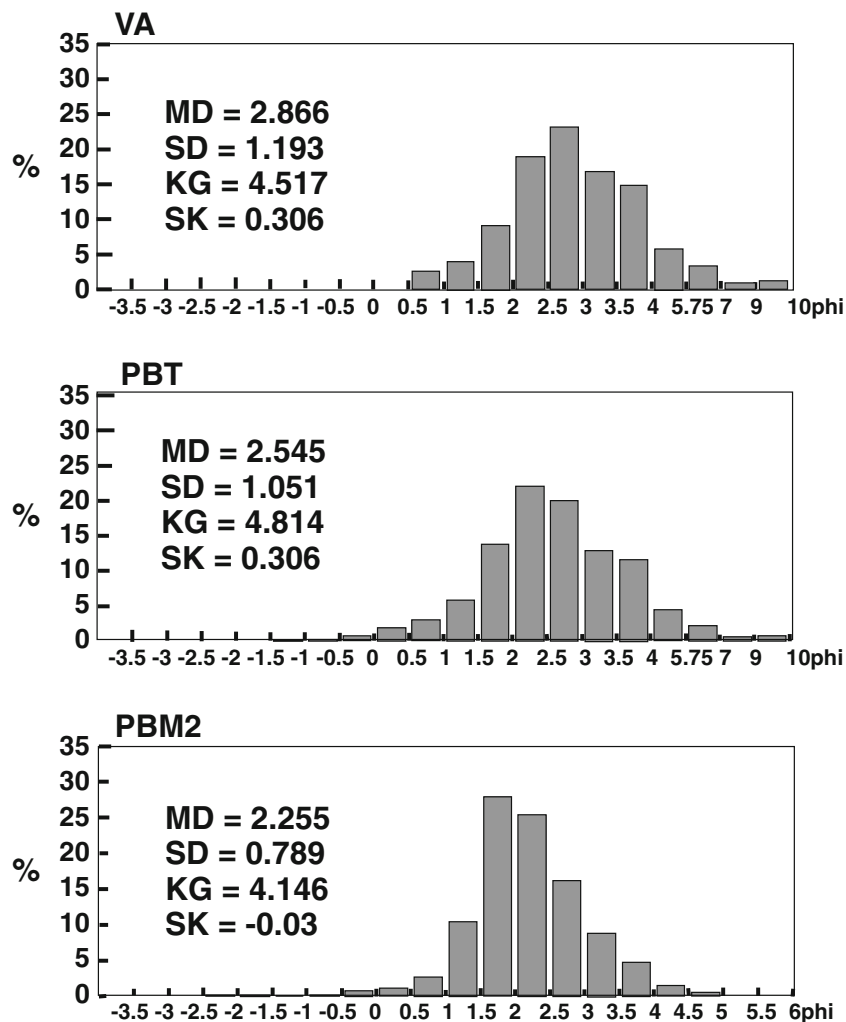

Fig. 4 Lithofacies of the Obra valley alluvial fill and mean values of granulation coefficients (Słowik 2007): $L A G$ lag deposits, $P B B$ bottom part of point bar, $P B M 1$ - lower segment of middle part of point bar, $P B M 2$ upper segment of middle part of point bar, $P B T$ top part of sampling frequency and the number of samples was increased (see parameter settings in Table 1b) to improve the measurement resolution. Then the GPR images were processed using ReflexW 5.0 software. Subtract-mean (dewow) filter eliminated low-frequency noise. This tool calculates a running mean value for each value of a GPR
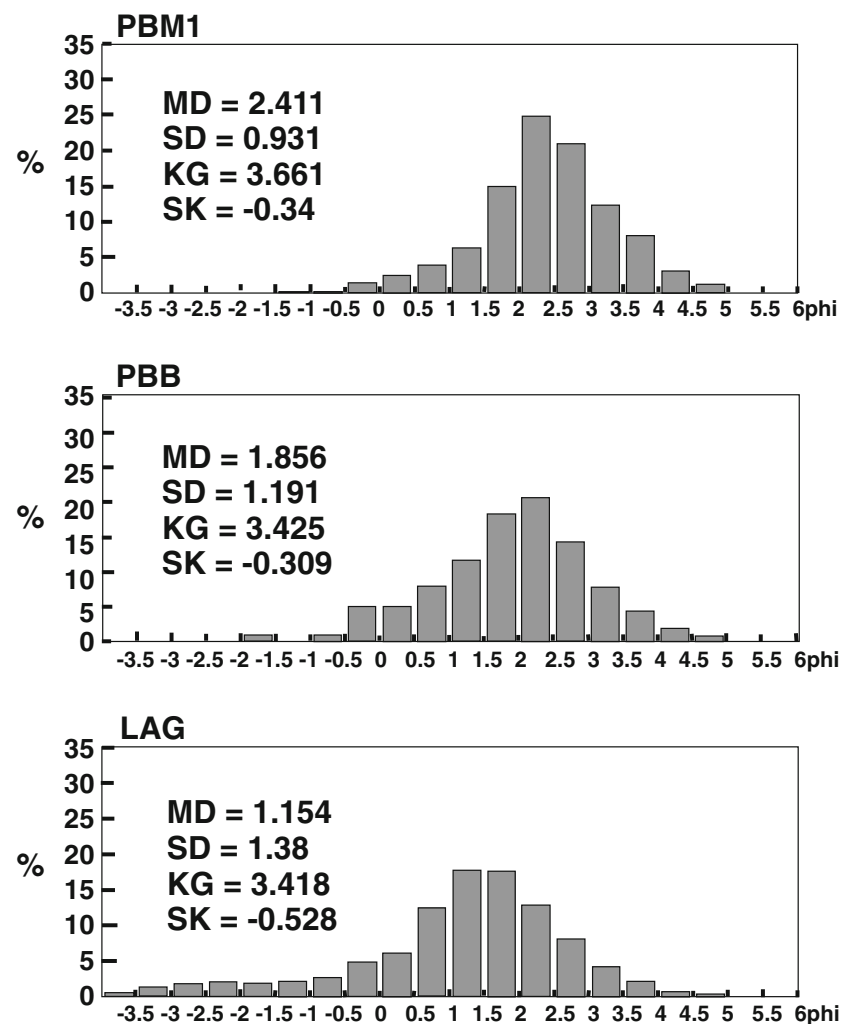

point bar, VA vertical accretion deposits. The figure presents a distribution of the sediment granulation in $0.5 \Phi$ sections and the mean values of granulation coefficients. $M D$ mean diameter, $S D$ standard deviation, $K G$ kurthosis, $S K$ skewness 
Table 1 Parameter settings during the GPR measurements for profile 3 (A) and profiles 1 and 4 (B) using 100 and $250 \mathrm{MHz}$ antennae

\begin{tabular}{lll}
\hline & A & B \\
\hline 100 MHz antenna & & \\
Sampling frequency (MHz) & $6,411.9$ & $9,617.8$ \\
Number of samples & 686 & 990 \\
Number of stacks & 8 & 8 \\
Time window (ns) & 107 & 102.9 \\
Trace interval (m) & 0.099 & 0.099 \\
250 MHz antenna & & \\
Sampling frequency (MHz) & $4,274.6$ & $12,823.8$ \\
Number of samples & 246 & 452 \\
Number of stacks & 8 & 8 \\
Time window (ns) & 57.5 & 35.2 \\
Trace interval (m) & 0.099 & 0.099 \\
\hline
\end{tabular}

trace. The running mean is then subtracted from the central point and allows the elimination of a possible lowfrequency part (Sandmeier 2008). Boll et al. (1996) and Vanderberghe and van Overmeeren (1999) reported that during reflection profiling, dipping layers are shifted compared to their actual position. For this reason, the frequency-wavenumber ( $\mathrm{f}-\mathrm{k}$ ) migration procedure was applied to correct dips of reflections. This procedure transforms the $\mathrm{f}-\mathrm{k}$ range based on a constant electromagnetic wave velocity; its application is strongly dependent on the number of wavelengths characterizing GPR traces (Sandmeier 2008). Automatic gain control (AGC) gain and manual gain $(y)$ filters enhanced the low-amplitude reflections and intensified the GPR signal in the places with useful, but low amplitude, information. AGC gain enables the creation of equally distributed amplitudes of the GPR signal in $y$-direction (time/depth axis; Sandmeier 2008). The manual gain $(y)$ option allows the definition of a digitized gain curve in the $y$-direction and to then apply this curve on the GPR data (Sandmeier 2008). It should be noted that the gain tools alter the original amplitudes of the GPR signal. Background removal was applied to make visible the useful information which was covered by temporally consistent noise (Sandmeier 2008). Static correction was used for elevation corrections where necessary (see Fig. 5, the upper part of profile 3).

The GPR data can be verified by the sedimentary information derived from detailed drilling which is a very

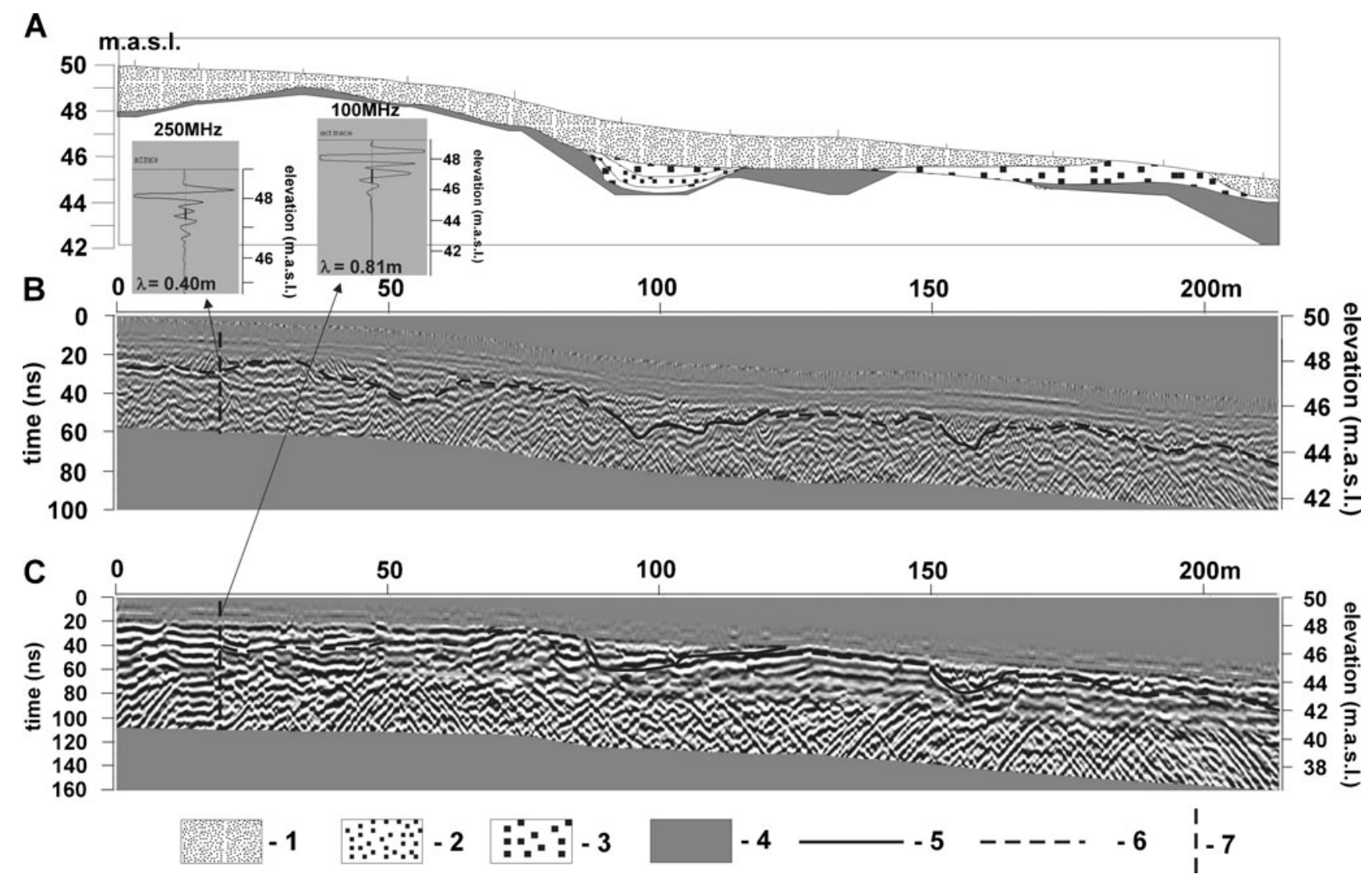

Fig. 5 Geologic structure of alluvial deposits in the upper part of profile 3 recognized by geologic survey (a) and the GPR measurements using the $250 \mathrm{MHz}$ (b) and the $100 \mathrm{MHz}$ (c) antenna; 1 fine sands, 2 coarse sands, 3 gravels, 4 basal till, 5 the spatial extent of gravel beds, 6 the contact between sand and gravel deposits and basal till, 7 single GPR traces chosen for wavelength analysis, $\lambda$ wavelength 
strong support for interpretation (Vanderberghe and van Overmeeren 1999; Bersezio et al. 2007). The depth scale of the GPR images was determined on the basis of the correlation of the radar reflections with the geologic profiles presented by Słowik (2007). One hundred twenty tube sample borings were done along five profile lines (Słowik 2007; see Fig. 3). The alluvial/glacial deposit interface was reached only in three places due to the coarse sands making manual tube sample borings difficult. However, it allowed the connection of the types of the GPR signal with the changes in lithology and determining the thickness of the alluvial fill in all the GPR profiles (see Figs. 5, 6, 7, and 8). Furthermore, distinct GPR reflections were correlated in all the profiles with the contact between the bottom of organic deposits and the top of coarse sands. All the GPR profiles presented in this paper have vertical scales measured in nanoseconds (ns) two-way travel time.

Furthermore, wavelengths of chosen GPR traces were analyzed to study differences in the resolution of the GPR images. Both frequencies (250 and $100 \mathrm{MHz}$ ) antennae surveys were taken into account. The single GPR traces analyzed in detail were chosen from the places where alluvial structures or sorts of alluvial deposits could be distinguished from the GPR images (20 m of the upper part of profile 3, Fig. $5 ; 100 \mathrm{~m}$ of the floodplain part of the profile, Fig. 6; $60 \mathrm{~m}$ of profile 1, Fig. 7; and $40 \mathrm{~m}$ of profile 4, Fig. 8). It should be noted that the wavelengths were analyzed using unprocessed GPR images due to loosing the natural value and shape of the GPR amplitudes when applying the AGC gain function. The values of the wavelengths were determined at the depth range of $1-$ $2.5 \mathrm{~m}$ bls where most of the alluvial structures occurred. Moreover, a single GPR trace from profile 3 measured in Siercz, $30 \mathrm{~km}$ downstream of the research area (Słowik 2011), was presented in this study (see Fig. 8d) to compare the influence of measurement conditions on the resolution of the GPR images.

Ten organic sediment samples were collected during the geologic surveys to estimate the radiocarbon age and to determine the chronology of the Obra River bed migration phases. The analyses were done in the Gliwice Radiocarbon Laboratory using the gas proportional counting technique (Pazdur et al. 2003). The age of five of the samples in profiles 1 and 3 was presented by Słowik (2007). The age of the remaining five samples, as well as the lithology of the upper part of profile 3 , are shown in this paper for the first time and was used to increase the accuracy of the migration phases. Beside the radiocarbon data, the migra-

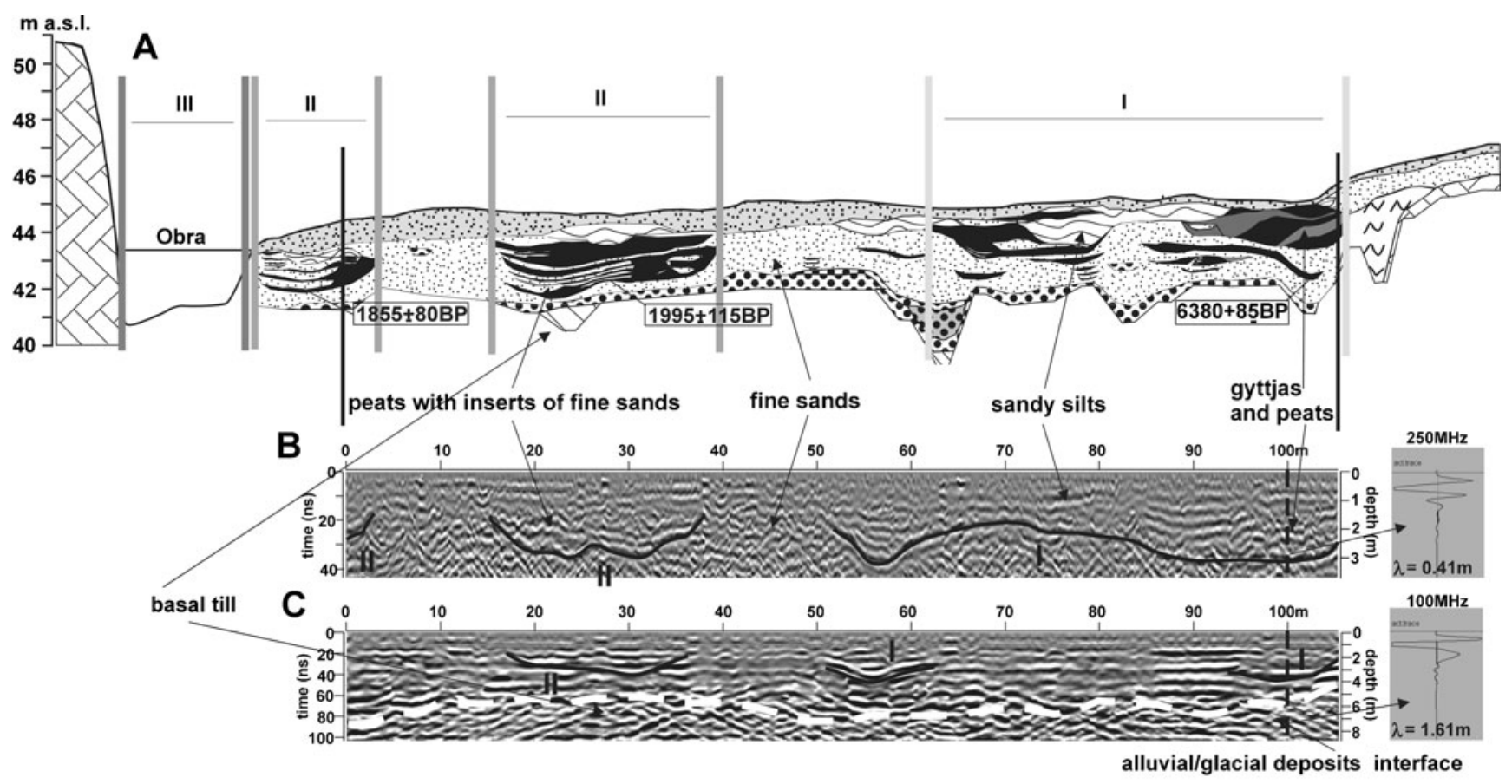

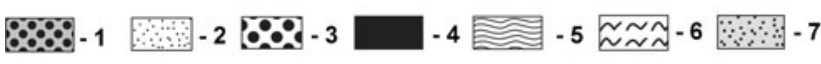

Fig. 6 The spatial extent of migration phases of the Obra River bed marked on geologic profile 1 (a) (Słowik 2007) and on the basis of the GPR measurements using the $250 \mathrm{MHz}$ (b) and the $100 \mathrm{MHz}$ (c) antenna; 1 coarse sands with organic matter, 2 fine sands, 3 coarse sands, 4 peats, 5 sandy silts, 6 clays, 7 fine sands with organic matter,
8 gyttja, 9 basal till, 10 calcareous sediments, 11 places of borings, 12 migration phases determined on the basis of geologic and radiocarbon data (Słowik 2007) and on the basis of the GPR surveys, 13 range of the GPR profiles, 14 single GPR traces chosen for wavelength analysis 


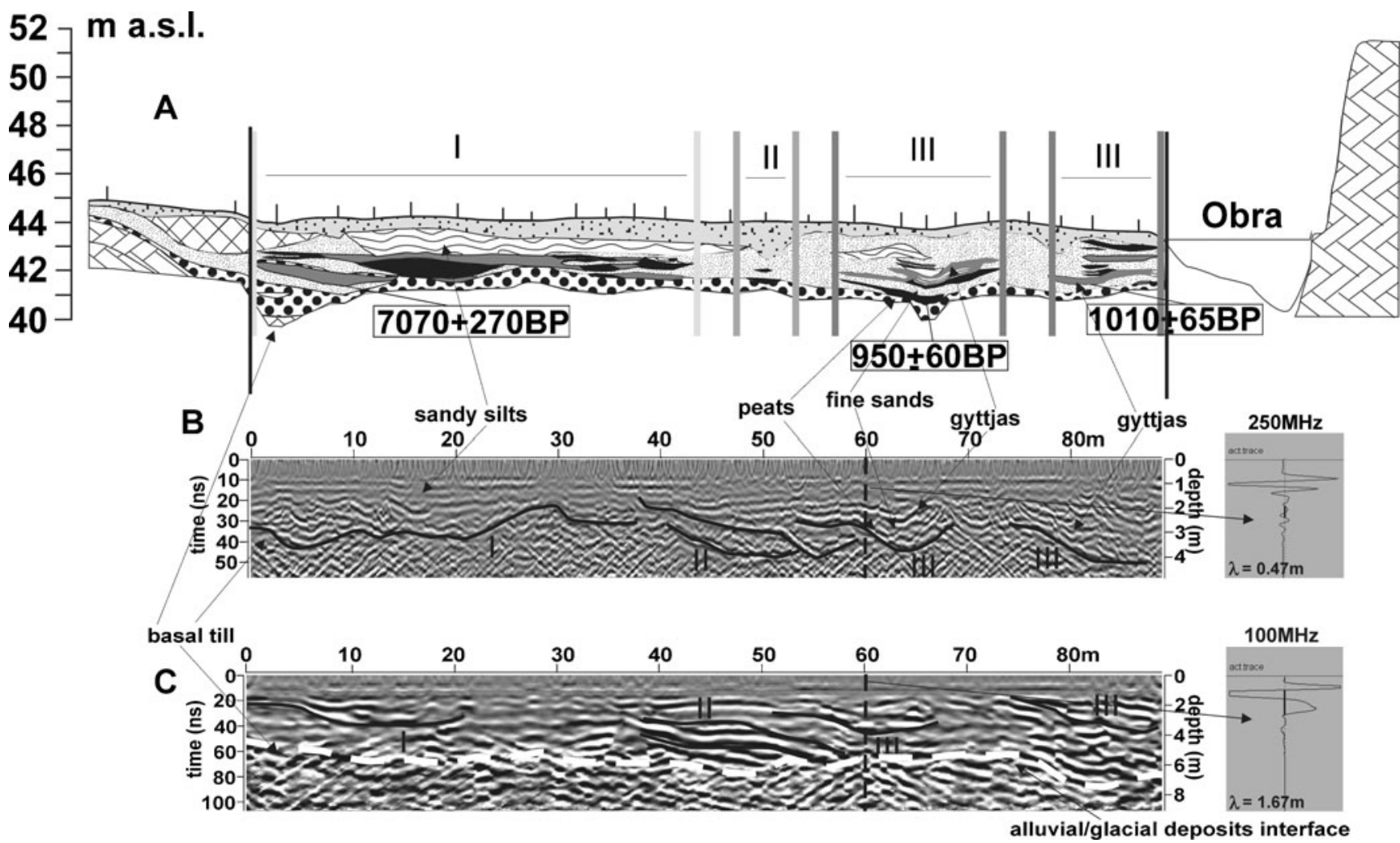

Fig. 7 The spatial extent of migration phases of the Obra River bed marked on the floodplain part of geologic profile 3 (a; Słowik 2007) and on the basis of the GPR measurements using the $250 \mathrm{MHz}(\mathbf{b})$ and the $100 \mathrm{MHz}(\mathbf{c})$ antenna. For explanations, see Fig. 7 caption

tion phases were distinguished on the basis of lithologic similarities in the studied geologic profiles and the GPR measurements.

Archival cartographic materials presented in this paper (see Fig. 2) originate from the eighteenth $(\sim 1750)$ and the nineteenth $(1828,1894)$ century. The maps provided the information on the transformations of the Obra River bed within the detailed research area. The accuracy of the earliest map is low. The cartographic material has no maintained distances and provides only general information about the changes of the riverbed pattern. The other two maps were edited at a scale of 1:25,000 and were made by the General Staff of Prussian Army using triangulation measurement and their accuracy is comparable with the modern maps.

\section{Results}

4.1 Phase of early development of the valley

\subsubsection{GPR reflection patterns}

The traces of this phase were detected in the upper part of profile 3 (see Fig. 5) within an elevated part of the study area (see Fig. 3). Horizontal and curved, concave-up reflection patterns can be distinguished in the GPR images (see Fig. 5b and c). Faint horizontal GPR reflections can be seen in the top part of the 100 and the $250 \mathrm{MHz}$ images. The concave, curved-up pattern appears between 30 and 70, 85-120, and 150-165 m of both images (see Fig. 5b and c). Furthermore, many hyperbolic diffraction appear in the bottom parts of the GPR profiles.

\subsubsection{Interpretation}

The horizontal reflections represent fluvioglacial fine sands and gravels recognized by coring in the top part of the geologic profile (see Fig. 5a). However, the place where the gravels appear in the land surface (180-200 $\mathrm{m}$ of geologic profile) was not marked by any change of the reflection pattern. The concave, curved-up GPR signal is consistent with two coarse sand and gravel beds situated between 85 and 120 and $150-165 \mathrm{~m}$ of the profile (see Fig. 5a). The depth of the structures reaches $3.5 \mathrm{~m}$ below the land surface. Sand and gravel deposits are particularly susceptible to georadar imaging when devoid of clay minerals (Belina et al. 2009). The beds were detected despite a small difference in electromagnetic wave velocity between sands and gravels which was also noted by Vanderberghe and van Overmeeren (1999). When comparing the geologic profile and the GPR images (see Fig. 5), it can be seen that the 


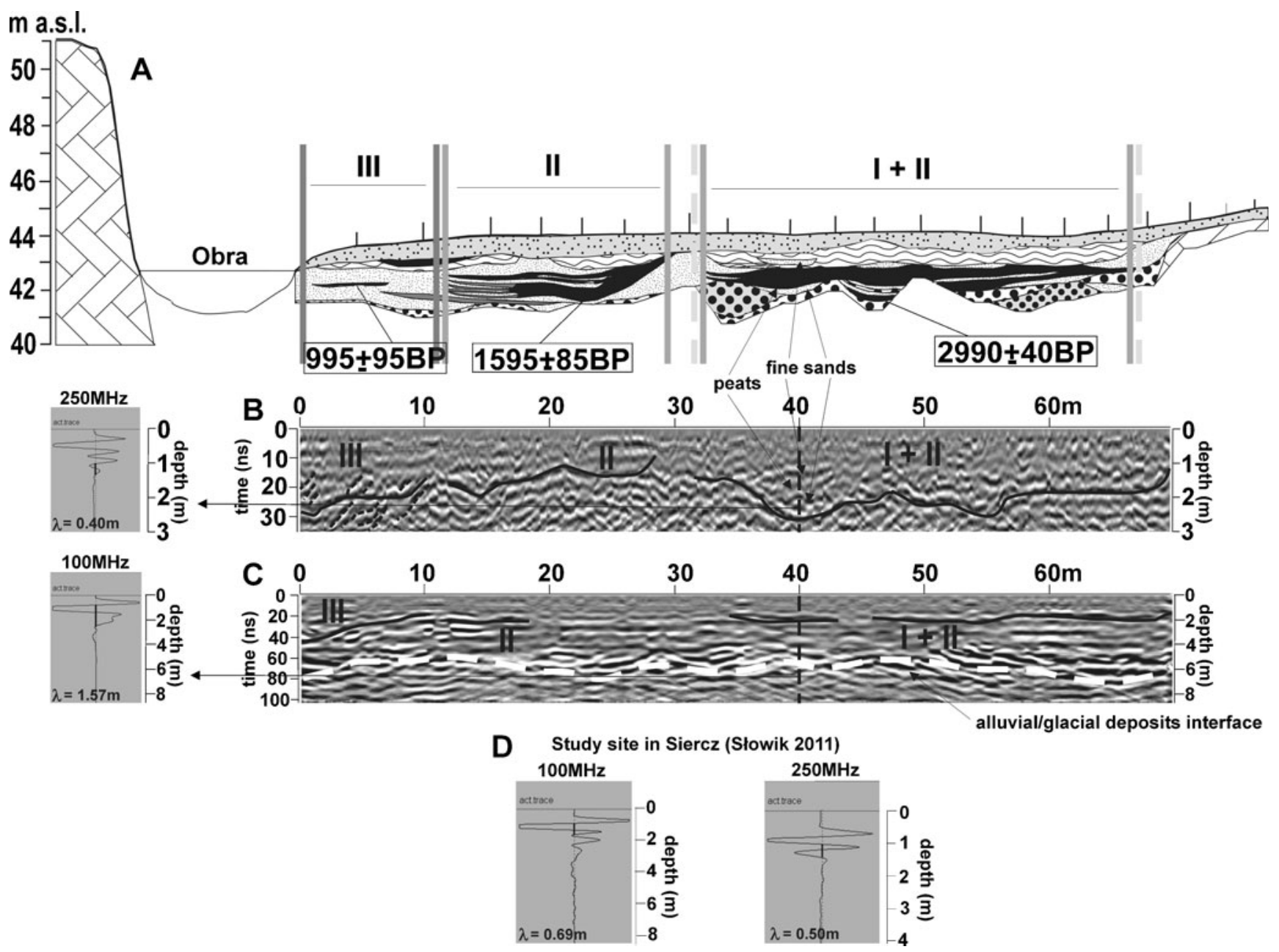

Fig. 8 The spatial extent of migration phases of the Obra River bed marked on geologic profile 4 (a) (Słowik 2007) and on the basis of the GPR measurements using the $250 \mathrm{MHz}$ (b) and the $100 \mathrm{MHz}$ (c)

geophysical surveys allowed a more detailed analysis of the spatial extent of the gravel fills. However, it should be noted that the curved reflection pattern between 30 and $70 \mathrm{~m}$ of the 100 and the $250 \mathrm{MHz}$ GPR section is not in agreement with lithologic information. There is no gravel fill detected by coring in this part of the profile (see Fig. 5a). It can be seen that coring here reached only $1.5-$ $1.8 \mathrm{~m}$ below the land surface and it is possible that a gravel bed is present beneath the thin layer of till. It is also possible that layering of fine material was underlain here. Layers of fine sands can be marked by higher amplitudes in fluvioglacial deposits as was shown by Asprion and Aigner (1999).

The geologic profile shows that sand and gravel sediments are underlain by the basal till. The glacial deposits are marked on the echograms by much distorted or faint reflectors with many hyperbolic diffraction (see Fig. $5 \mathrm{~b}$ and c). It was possible to mark the contact between the sand and gravel deposits and the till on the GPR images (see Fig. 5b antenna. d A single GPR trace from GPR section 3 in study site in Siercz (Słowik 2011). For explanations, see Fig. 7 caption

and c). The sands and gravels/till interface is in agreement with the geologic profile (see Fig. 5a). However, the GPR pattern within the basal till is represented by various types of GPR reflections, especially in Fig. 5c (100 MHz measurement). Here, the glacial deposits are marked by faint, horizontal, or slightly dipping reflectors followed by a zone with dense network of diffractions. There are two possible explanations:

- The diffractions appear at 5.5-6 m depth below land surface and might be joined with limited depth penetration of the GPR surveys in glacial deposits.

- The zone with dense diffractions can be seen throughout the bottom part of the GPR section (see Fig. 5b) and may be the effect of a lithologic change in the glacial deposits. Possibly, the deposits marked by the faint horizontal or slightly dipping reflections have significant admixtures of sand or gravel material. The hyperbolic diffractions cover the till with clay minerals 
that attenuates the GPR signal. These findings are partly in agreement with Ekes and Hickin (2001) who reported that basal till was marked by poorly defined, or lack of, reflections.

\subsection{Migration phase I: 7070-2990 BP}

\subsubsection{GPR reflection patterns}

The following types of GPR reflections were discerned in the parts of the floodplain containing the record of migration phase I (Słowik 2007):

- Curved, concave-up reflections can be seen between 53 and $105 \mathrm{~m}$ of profile 1 (see Fig. 6b), 0 and $37 \mathrm{~m}$ of profile 3 (see Fig. $7 \mathrm{~b}$ ), and 32 and $70 \mathrm{~m}$ of profile 4 (see Fig. 8b). The GPR signal appears at a depth ranging from $2.5 \mathrm{~m}$ bls in profile 4 to $3.5 \mathrm{~m}$ bls in profile 3 (see Figs. $7 \mathrm{~b}$ and $8 b$ ).

- Faint horizontal reflections are present between 50 and 75 and $82-105 \mathrm{~m}$ of profile 1 (see Fig. 6b), between 0 and $37 \mathrm{~m}$ of the top part of profile 3 (see Fig. $7 \mathrm{~b}$ ) and between 32 and $70 \mathrm{~m}$ of the top part of profile 4 (see Fig. 8 b).

- Wavy and slightly dipping reflections appear at $100 \mathrm{~m}$ of profile 1 at $2.0 \mathrm{~m}$ bls. More reflectors of that sort can be seen between 1 and $18 \mathrm{~m}$ of profile 3 at $1.8 \mathrm{~m}$ bls. In case of profile 4 , wavy reflectors appear between 38 and $42 \mathrm{~m}$ at the depth of $2.0 \mathrm{~m}$ bls and between 50 and $68 \mathrm{~m}$ at the depth of 1.5-2.0 $\mathrm{m}$ bls.

- The lack of reflections or hyperbolic diffractions appears throughout the bottom parts of all studied profiles (see Figs. 6, 7, and 8).

\subsubsection{Interpretation}

The curved, concave-up reflections can be defined here as peats/fine sands and fine/coarse sands interfaces. In general, the spatial range of the reflections is in agreement with the range of the organic deposit fills marking migration phase I in profiles 1, 3, and 4 (see Figs. 6, 7, and 8). The faint horizontal reflections in the top parts of the profiles represent fine sands with organic matter and sandy silts. However, it was not possible to identify the contacts between the two sorts of deposits. As was noticed by Ekes and Hickin (2001), individual GPR reflections cannot be strictly interpreted as particular depositional features. Higher amplitude reflections appear in some places; for example, at $78 \mathrm{~m}$ of profile 1 (see Fig. 6b). In this case, they mark sandy silts. It should be noted that silt sediments correlate well with a faint GPR signal in profile 3 (see
Fig. $7 \mathrm{~b} ; 10-35 \mathrm{~m}$ of the profile). It was also possible to connect some of the wavy and dipping reflectors with the type of sediment. A slightly dipping reflector marking a peats/gyttjas interface was observed at $100 \mathrm{~m}$ of the profile (see Fig. 6b). Distinct reflections are consistent with fine sand layers and the faint ones represent the layer of peat deposits between 38 and $42 \mathrm{~m}$ of profile 4 (see Fig. 8b). Furthermore, the bottom of alluvial deposits was recognized in coring at $63 \mathrm{~m}$ of profile 1 (see Fig. 6a) and at $3 \mathrm{~m}$ of profile 3 (see Fig. 7a). Here, alluvial/glacial deposits interface was correlated with a distinct change of the GPR signal from curved, concave-up reflections to hyperbolic diffractions. Thus, it was possible to determine the thickness of the alluvial fill in profiles 1 and 3 . The interface can be clearly seen especially in the $100 \mathrm{MHz}$ GPR images (see Figs. 6c and 7c). Moreover, the spatial extent of the migration phase determined by the GPR measurements is consistent with the extent determined by Słowik (2007) on the basis of sedimentary and radiocarbon data.

\subsection{Migration phase II: $2990-1010$ BP}

\subsubsection{GPR reflection patterns}

The following GPR patterns were discerned in the deposits belonging to the discussed migration phase:

- Sets of curved and concave-up reflections were observed in profile 3 (see Fig. $7 \mathrm{~b}$ ) between 38 and $58 \mathrm{~m}$ of the profile. They appear at the depth range from 2.0 to $4.0 \mathrm{~m}$ bls.

- Single concave-up reflections are present between 15 and $38 \mathrm{~m}$ of profile 1 (see Fig. $6 \mathrm{~b}$ ) at $1.5-3.0 \mathrm{~m}$ bls depth and between 12 and $28 \mathrm{~m}$ of profile 4 (see Fig. 8b) at 1.0-2.0 m bls depth.

- Wavy and slightly dipping reflections usually appear above the concave-up reflections in all the profiles (see Figs. 6, 7, and 8).

- Similar to migration phase I, faint horizontal, or lack of, reflections were present in the top part of the profiles.

\subsubsection{Interpretation}

The sets of concave-up reflections appear in profile 3 in fine sands and are a record of erosion surfaces. Detecting the erosion surfaces extended the spatial range of the migration phase in profile 3 (see Fig. 7b). Before conducting the geophysical surveys, it had been interpreted that the record of the phase in alluvial deposits was represented by two thin peat layers (geologic profile; see Fig. 7a, Słowik 2007). 
Single concave-up reflectors can be also interpreted as peat/fine sands interfaces marking the spatial extent of the organic deposit fills. The spatial extent of one of the riverbeds of this migration phase can be seen in the GPR image measured with the $250 \mathrm{MHz}$ antenna in profile 1 (see Fig. 6b). Only a fragment of the second, simultaneously functioning riverbed was marked (see Fig. 6b) because dense vegetation did not allow the completion of the GPR measurement close to the riverbed. Peats with inserts of fine sands between 17 and $30 \mathrm{~m}$ of the profile (see Fig. 6a and b) correlate well with wavy and slightly dipping reflections. However, the GPR reflections do not illustrate every single insert of fine sands. Leclerc and Hickin (1997) reported that some gravel lenses do not give clear GPR reflections. Some of them are marked due to changes in saturation conditions within coarse deposits. The authors also noted a poor correlation between the boundaries of the distinguished radar facies and core data. It should be noted that the deposits of sand bars alternating with the organic fills of migration phases I and II (see Fig. 6a, 38-51 m of profile 1) are also featured with a wavy and dipping reflection pattern. A similar GPR signal can be seen in the other sand bar in profile 4 (28-32 $\mathrm{m}$ of the profile; Fig. 8a). The faint horizontal or lack of the GPR reflections refer to the fine sands and silts in the top parts of the floodplain. The pattern does not allow the determination of the interface between the two sorts of sediments.

\subsection{Migration phase III: $1010-0$ BP}

\subsubsection{GPR reflection patterns}

The third of the migration phases is represented by peat deposits situated in the vicinity of the modern riverbed (Słowik 2007). The following reflection patterns were distinguished in the deposits of the migration phase:

- Curved, concave-up reflections are present between 53 and $68 \mathrm{~m}$ of profile 3 (see Fig. $7 \mathrm{~b}$ and c) at 3.0$3.5 \mathrm{~m}$ bls.

- Dipping reflections can be seen in near bank zones in profiles 3 and 4 (see Fig. 7b, c and 8b, c) at the depth of $1.5-3.5 \mathrm{~m}$ bls.

\subsubsection{Interpretation}

The concave-up GPR signal in profile 3 marks the peats/ coarse sands interface (see Fig. 7a and b). There are some high-amplitude reflections above the detected boundary (see Fig. 7b). They can be correlated with gyttjas, fine sands, and peats between 53 and $68 \mathrm{~m}$ of profile 3 (see Fig. 7a and b). Similar results were shown by Vanderberghe and van Overmeeren (1999) who observed continuous reflections produced by a peat layer situated $2-3 \mathrm{~m}$ bls. Moreover, a double-channel-shaped reflection measured by these authors slightly resembles the shape of the organic fills of migration phase III in the profile (see Fig. 7b, c). A similar GPR signal was presented by Leclerc and Hickin (1997) who interpreted sets of inclined reflections as a channel island with adjacent chute channel. Dipping reflectors indicate layering of fine sands within the point bar using the 250 and the $100 \mathrm{MHz}$ antenna (see Fig. 7b, c and $8 \mathrm{~b}, \mathrm{c}$ ). A similar GPR pattern was interpreted by Ekes and Hickin (2001) as delta foreset beds (steeply inclined clinofroms) or migration channel bars (sigmoidal reflection pattern). Granulometric analyses of sediment cores taken from the point bars indicated upward-fining facies sequences. The sequences were also noted within the channel bars belonging to the two older migration phases (Słowik 2007).

These results have allowed an interpretation of the particular migration phases (Fig. 9). The gravel beds in the upper part of profile 3 (see Fig. 5) were formed in a high-energy depositional environment, possibly with the additional activity of proglacial waters. Migration phase I (Fig. 9) is represented by $40 \mathrm{~m}$ wide fills of strongly decomposed peats and gyttjas (see Figs. 6a, 7, and 8a). This may suggest that the riverbed was wider at that time than the modern one; its width ranges from $18 \mathrm{~m}$ near profile 3 and $25 \mathrm{~m}$ near profile 4 (Młynarczyk and Słowik 2008). Furthermore, the functioning of two migration phases in the same place is possible in profile 4 (migration phases I + II; Fig. 9). Migration phase II was marked by $15-20 \mathrm{~m}$ wide fills of peat deposits containing numerous inserts of fine sands (see Figs. 6a and 8a). Furthermore, the Obra River could have had channel islands and at least two simultaneously functioning riverbeds during migration phases II and III (see Fig. 9); the age of two organic sediment fills in profiles 1, 3, and 4 is comparable (see Figs. 6a, 7, and 8a). A relatively poorer record of the youngest migration phase (1010-0 BP) in the Obra valley alluvial fill (in comparison with two older phases) may suggest that this stage is still active; exposures of fluvioglacial and glacial deposits can be seen in high concave banks of the Obra River.

\section{Discussion}

\subsection{Antennae resolution and depth range}

The measurements conducted using the $250 \mathrm{MHz}$ antenna allowed the analysis of the Obra River floodplain architecture. Erosion surfaces, sediment interfaces, layering of sand deposits, channel fills, and, in some places, flood deposit units were detected. The $100 \mathrm{MHz}$ antenna surveys allowed a more general analysis; only a fragmentary picture of the 


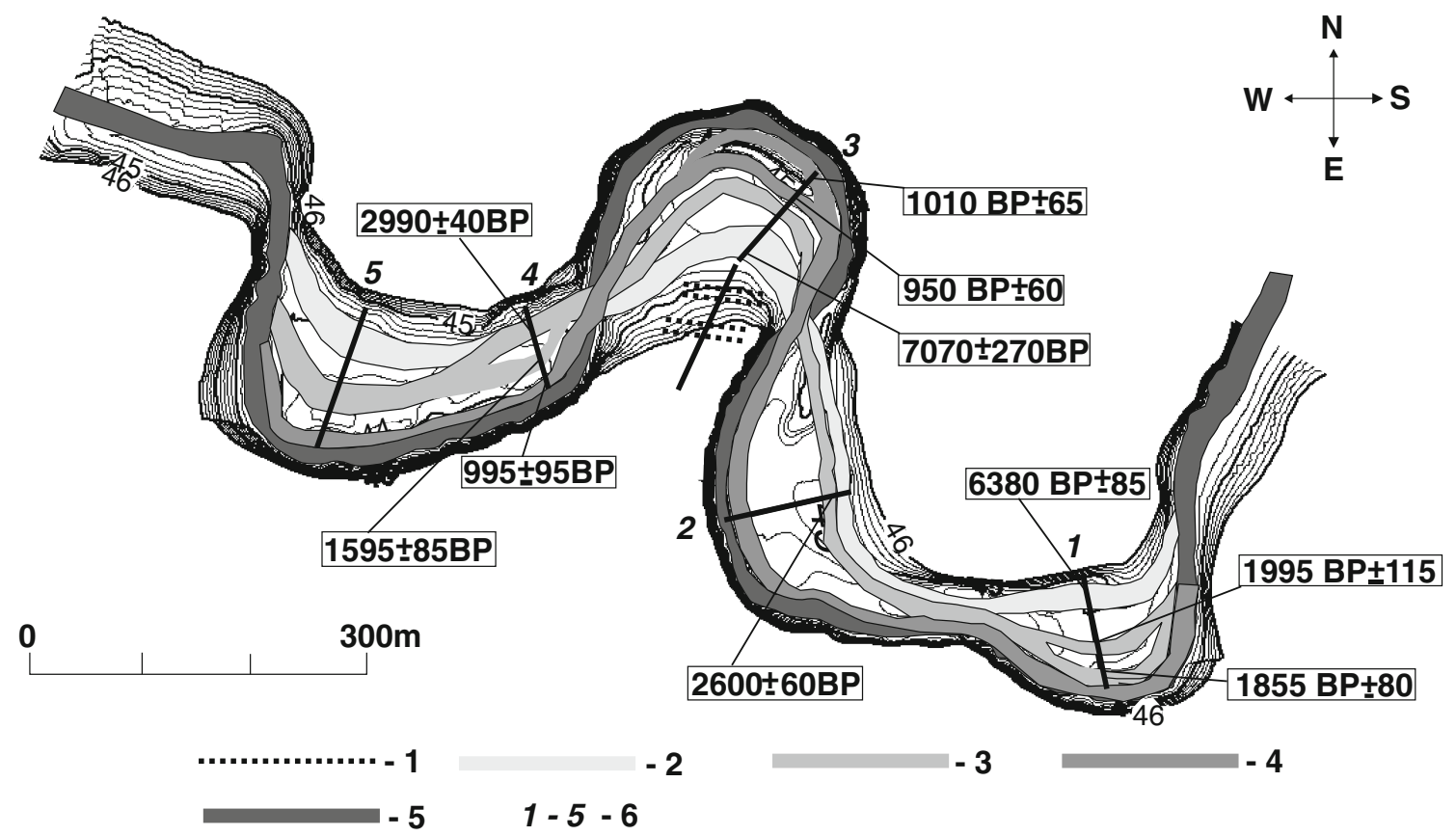

Fig. 9 Migration phases of the Obra River bed determined on the basis of radiocarbon data and lithologic variability of alluvial deposits; 1 traces of gravel beds (early development of the Obra River valley), 2

phase I (7070-2990 BP), 3 phase II (2990-1010 BP), 3 phase III (1010-0 BP), 5 the modern river bed, 6 geologic profiles

migration phases can be seen in the $100 \mathrm{MHz}$ images (see Figs. 6c, 7, and 8c). Furthermore, gravel fills could be distinguished in the upper part of profile 3 (see Fig. 5c), however, their shape was marked in less detail in comparison with the higher frequency antenna. Wavelengths of single GPR traces were analyzed to study the differences in resolution of the GPR surveys. According to MALA (2008) the resolution of the 100 and $250 \mathrm{Mhz}$ antenna is 25 and $10 \mathrm{~cm}$, respectively. However, these values refer to optimal measurement conditions (MALA 2008). The resolution of GPR surveys is dependent on the wavelength of emitted signal; a GPR antenna resolution is one quarter of the wavelength (Bowling et al. 2007; Sass et al. 2010). During the measurements conducted in the Obra River valley, the wavelength of the $250 \mathrm{MHz}$ antenna signal varied from $0.40 \mathrm{~m}$ in the upper part of profile 3 (see Fig. $5 \mathrm{~b}$ ) to $0.47 \mathrm{~m}$ in the lower part of the profile (see Fig. 7b). Thus, the resolution of the measurements ranged from 0.10 to $0.12 \mathrm{~m}$. In case of the $100 \mathrm{MHz}$ surveys, the wavelength of the GPR signal varied from $1.57 \mathrm{~m}$ in profile 4 (see Fig. 8c) to $1.67 \mathrm{~m}$ in profile 3 (see Fig. 7c). As a result, the measurement resolutions ranged from 0.39 to $0.42 \mathrm{~m}$. The presented values show the reason for the differences in the geophysical record of the migration phases; the resolutions of the lower frequency antenna were very close to that presented by MALA (2008). The $100 \mathrm{MHz}$ antenna was more susceptible to the measurement conditions. It should be noted that organic and clay deposits, groundwater level, rough land surface, and dense

vegetation may attenuate a GPR signal (Van Heteren et al. 1998; Bano et al. 2000; Neal 2004; Schrott and Sass 2008). Boll et al. (1996) concluded that fine-coarse interfaces cannot be detected using the GPR method if the studied soil is too uniformly dry or wet. Kostic and Aigner (2007) concluded that strong contrasts (high amplitudes) in the GPR images are the effect of different volumes of water held in the pore space of deposits. Moreover, it was not possible to reconstruct such features as sediment grain type, shape, or orientation, as was claimed by Neal (2004), possibly due to the measurement conditions and the mixture of sediments within the floodplain (organic, sand, and gravel deposits).

The presented $100 \mathrm{MHz}$ wavelengths were compared to the GPR surveys conducted in Siercz, $30 \mathrm{~km}$ upstream of the study site (Słowik 2011). The research area in Siercz has similar geologic structures (fine sands, peats, and gyttjas underlain by coarse sands) but has a fairly level ground surface with relatively few obstructions (Słowik 2011). In case of the $100 \mathrm{MHz}$ survey in profile 3 in Siercz (see Fig. 8d; the GPR section can be seen in Słowik (2011)), the wavelength and resolution of the GPR signal was 0.69 and $0.17 \mathrm{~m}$, respectively. As a result, complex structures of a braided river system could be illustrated (Słowik 2011). In the present study, the resolution of 0.39 $0.42 \mathrm{~m}$ allowed the creation only of a fragmentary picture of the alluvial deposits. Taking into account similar geologic and groundwater conditions (the groundwater level was situated $1.0-1.2 \mathrm{~m}$ bls.), it can be suggested that 
the rough land surface and dense vegetation may be the main factors influencing the resolution of the $100 \mathrm{MHz}$ surveys. A successful application of $100 \mathrm{MHz}$ surveys to study alluvial structures in the case of a level floodplain was also presented by Leclerc and Hickin (1997). The present research area has a floodplain with a rough land surface and dense vegetation. The upper part of profile 3 (see Fig. 5) was the only exception with the land surface relatively suitable for the GPR measurement. The $100 \mathrm{MHz}$ surveys, which were conducted there, were featured with a relatively shorter wavelength $(0.81 \mathrm{~m})$ and better resolution (0.2 m; Fig. 5c). As a result, this GPR image (see Fig. $5 \mathrm{c}$ ) was easier to interpret compared to the floodplain profiles. Furthermore, no significant difference was noted when comparing the wavelengths and resolutions of the $250 \mathrm{MHz}$ antenna surveys in the studied area and in Siercz (Słowik 2011). The reason, possibly, lies in the antenna's dimension; it was easier to draw steadily the smaller (the $250 \mathrm{MHz}$ ) antenna in the rough floodplain surface to avoid the signal disturbances. However, this matter requires further field measurement in a range of conditions.

Moreover, it should be noted that increased sampling frequency and number of samples (see Table 1) did not help to eliminate the influence of the rough surface and dense vegetation and to achieve the $100 \mathrm{MHz}$ image more suitable for the interpretation. Furthermore, changing the measurement parameters altered the depth penetration. The $250 \mathrm{MHz}$ surveys reached $4.5 \mathrm{~m}$ bls in profile 3 (see Fig. 7b) and only 3.5 and $3.0 \mathrm{~m}$ bls in profiles 1 and 4 , respectively (see Figs. $6 \mathrm{~b}$ and $8 \mathrm{~b}$ ). It can be seen that increasing the parameter values during the $100 \mathrm{MHz}$ antenna surveys resulted in a relatively small shortening of the time window from 107 to 102.9 ns (see Table 1). As a result, the depth of penetration did not vary much between the profiles $(8.2 \mathrm{~m}$ bls in profile 4 (see Fig. $8 \mathrm{c}$ ) and $8.5 \mathrm{~m}$ bls in profile 3 (see Fig. 7c)).

\subsection{Migration of meandering channels}

This study has allowed the establishment of the sequence of erosion and accumulation processes forming the meander bends. A lateral stagnant water channel might have been formed in the vicinity of the Obra River bed during periods of long-lasting high water stages (Słowik et al. 2010). In such channel, peats and gyttjas were being deposited. The type of the accumulated sediment was dependent on changes of the water level and sedimentary environment. The accumulation of organic deposits was disturbed with inserts of fine sands. The layers of the mineral deposits are the effect of intensive flood events taking place during the periods of high water stages. Thus, the organic sediment fills mark the places where the riverbed was functioning in the past. Point bars were formed on convex banks of the riverbed during periods of low water stages and relatively lower activity of lateral erosion processes. The sand bars separated the fills of organic sediments representing particular migration phases. Traces of its formation (layering of fine sands within point bars) can be seen in the GPR images (see Fig. 7b, c and 8b, c). Such structures were also detected by Vanderberghe and van Overmeeren (1999), Ekes and Hickin (2001), Skelly et al. (2003), and Lunt et al. (2004). A theoretical analysis of bar formation in unsteady flow (Tubino 1991 in Lunt et al. 2004) suggests that unit bars are mostly modified during falling flow stages. Kostic et al. (2005) concluded that the presence of stratified sand deposits within glaciofluvial gravel delta is the effect of decreasing flow conditions at the final stage of the formation of the sedimentary deposits. When the frequency of high water stages and flood events increased again, the described sequence of erosion/deposition processes was repeated. Midchannel bars appeared during migration phases II and III when at least two river channels were functioning simultaneously (see Fig. 9). According to Lunt et al. (2004), midchannel bars in a curved reach of the main channel can be formed by both chute cut-off of a point bar and deposition of lobate unit bars within the main channel. Luchi et al. (2010) observed that formation of a midchannel bar was preceded by bank erosion and widening of the riverbed. Next, the division of flow around the bar became unbalanced causing erosion at one bank and deposition in the opposite branch (Hooke 1995 in Luchi et al. 2010). Despite detected functioning of simultaneous riverbeds during last 3,000 years BP (see Figs. 6a, 7a, 8a, and 9), the granulation features of the Obra River deposits suggest a meandering pattern. Upward-fining facies sequence was detected in analyzed vertical profiles collected from point bars (Słowik 2007). According to Allen (1977), there is no distinct difference between meandering and braided streams in the situation where a sinuous riverbed is divided by a mid-channel bar.

The formation of the channel islands and numerous inserts of fine sands in the peat deposits that belong to migration phases II and III suggests that the frequency and the magnitude of floods in the lower course of the Obra River must have increased during the last 3,000 years. In general, these findings correspond with the flooding phases discerned by Starkel et al. (2006). It should be noted that the frequency of floods and transformations of riverbed pattern are strongly dependent on the local features of a river basin (Krzyszkowski 1996); all the flooding phases were not recorded in the Obra River alluvial deposits. However, the beginning of migration phase I (7,000 years BP) corresponds with the 7.0-6.7 ky BP flooding phase discerned by Starkel et al. (2006). Similar connections can be found in the case of the younger migration phases; Starkel et al. (2006) reported that the frequency of flood 
events increased during the last 3,000 calendar years. An increase of sediment load caused by land use and/or climatic changes could be one of direct reasons for the observed river pattern changes. Anthropogenic impacts on processes forming the meander bends are possible in the case of the youngest migration phase. The influence of the water dam at Bledzew, situated $20 \mathrm{~km}$ downstream of the research area, cannot be neglected. Such constructions usually result in intensive aggradation upstream (e.g., Bristow et al. 1999; Skelly et al. 2003). Such processes could have been active since the dam was built (years 19061911). The dam construction might have resulted in more frequent inundation of the valley floor. It is possible that the layer of fine sands with organic matter in the topmost part of the geological profiles (see Fig. 6a, 7 and 8a) is the record of the aggradation. Hydrotechnical works (construction of the Obra Canals; Fig. 1) were also conducted in the middle course of the river (Słowik 2011). However, the Obra Canals are too distant from the detailed study site to have a significant influence on alteration of the floodplain sediment record; there are several lakes between the canals and the lower course of the river, smoothing the amplitude of water stages, discharges, and floods.

There are many studies describing the active migration of meandering rivers (e.g., Hooke 1995, 2007a; Gay et al. 1998; Rowntree and Dollar 1999). Such studies refer to the riverbeds formed in highly erodible sand and gravel deposits, where a meander cutoff or avulsion of a riverbed may take place due to a single flood event. In case of the Obra River, such a process is possible after a long-term series of floods as high-bank meander necks are secured with dense vegetation and glacial deposits that are resistant to erosion. Hooke (1980 in Gilvear et al. 2000) and Ikeda (1989 in Gilvear et al. 2000) found out that cohesive bank sediments strongly influence the migration rate of a riverbed. The studied meander bends can be classified as confined because the glacial till in the river banks constrain its migration; the shape of the bends is asymmetrical at its apex (Młynarczyk and Słowik 2008). This is similar to the meanders studied by Nicoll and Hickin (2010). However, the confined meanders in Alberta and British Columbia, Canada, were characterized by downstream migration as coherent waveforms (Nicoll and Hickin 2010). Such a mechanism results in a small potential to preserve the traces of meander bend formation due to eroding and reworking alluvial deposits by the migrating riverbed. Furthermore, the modern floodplains of actively migrating rivers are of recent origin and could be dated within the period of historical maps (e.g., Gay et al. 1998; Hooke 2007a). The shape of the meanders studied by Gay et al. (1998) is similar to the studied section of the Obra valley. However, migration phases of the Powder River extend back to the year 1890 as its planform may change rapidly. The present research has allowed the determination of the formation of meander bends on a much longer timescale, including traces of early development of the valley. The migration of the Obra River meander bends (see Fig. 9) can be classified as the first of the three modes of meander development described by Hooke (2007b); very slow, continuous development is marked with regular and distributed evenly over time traces of old channels.

In addition to cohesive glacial sediments, dense vegetation also slows down migration of the Obra River bed. Significant changes in channel planform (avulsion, riverbed straightening, meander lobing) were observed in reaches with limited development of floodplain vegetation (e.g., Gilvear et al. 2000). The importance of riparian vegetation in stabilizing river banks was also underlined by Rowntree and Dollar (1999). They indicated that narrow and stable reaches have relatively finer bed material and tree-lined banks, and where dense vegetation decreases the channel width it may result in a period of overbank flooding (Rowntree and Dollar 1999). This may be the case of the Obra River valley where the modern inundation of the floodplain may also be triggered by the dam in Bledzew. It can be concluded that the Obra River, as well as probably other densely vegetated lowland rivers that form their valleys in erosion-resistant glacial deposits and with regular amplitude floods, that there is a high potential that the floodplain deposits will be preserved. The presented study has shown that it is possible to reconstruct the record of regularly acting erosion and deposition processes forming meander bends back to 7,000 years BP.

\section{Conclusions}

The GPR surveys were conducted along three profile lines within a meandering section of the Obra River. The measurement was calibrated with core data. The objectives of the present study were: (1) to compare the potential of conventional and geophysical methods to trace the migration phases of meander bends and (2) to study the preservation potential of lowland river valleys formed in glacial deposits. The following conclusions can be drawn on the basis of the research:

1. The GPR method allows the analysis of the spatial variability of alluvial deposits and helps to describe the way meander bends of a lowland river are formed. It was shown that the GPR method gives useful results in spite of a rough land surface and dense vegetation. The field conditions influenced the resolution of the $100 \mathrm{MHz}$ antenna, however, the surveys reached the alluvial/glacial deposits interface, which illustrated the thickness of the alluvial fill. A more detailed picture of alluvial sediment 
interfaces and erosion surfaces was achieved using the $250 \mathrm{MHz}$ antenna owing to its finer resolution.

2. Lowland river valleys formed in erosion-resistant glacial deposits may have a relatively high preservation potential for floodplain deposits. Due to slow but regular migration of meander bends, studies undertaken in such river valleys allow for the reconstruction of the mechanisms of erosion and accumulation processes on much longer timescales in comparison with actively migrating rivers.

3. The research enabled the establishment of the migration phases of meander bends back to 7,000 years BP and trace the early development of the Obra River valley. The processes forming the meander bends at high and low water levels were presented, including variability of flood frequency and functioning of at least two simultaneous river channels during the last 3,000 years. Such change of the riverbed pattern could be caused by climatic changes and/or anthropogenic influences which resulted in an increase of sediment transport in the riverbed.

The present research does not answer all questions and problems regarding the Obra River valley. In its lower course, further work is required regarding development of meander bends in other reaches. Both the downstream and upstream influence of the dam in Bledzew on processes forming the riverbed and valley floor is also worth studying. Research to retrace the natural riverbed pattern was conducted by Słowik (2011) in the middle course altered by the construction of the Obra Canals. However, detailed studies are needed in several more places to reconstruct a variety of riverbed patterns functioning there before anthropogenic intervention. Attention should be also paid to developing a methodology of GPR measurement. Yilmaz (1987 in Neal 2004) stated that the processing of GPR images cannot be entirely objective. Further studies should be done towards working out a universal set of parameters and tools that could be applied to all (or most) sedimentary environments. Another research question is what sort of field conditions (e.g., land surface, groundwater level, frozen ground) associated with various parameter settings (e.g., time window, sampling frequency, number of stacks) determine optimal (highest possible resolution) results of GPR surveys in various sedimentary environments? A complex study is required here.

Acknowledgments The author would like to thank Remigiusz Tritt, MSc and Mr. Przemysław Bielerzewski for their great help during the GPR measurement and geologic surveys. I also wish to thank Krzysztof Petka for improving the quality of the language and Philip N. Owens for making final edits regarding English, style and consisitency of the paper. Thoughtful suggestions and comments of Ramon J. Batalla and two anonymous reviewers significantly improved the quality of the paper.
Open Access This article is distributed under the terms of the Creative Commons Attribution Noncommercial License which permits any noncommercial use, distribution, and reproduction in any medium, provided the original author(s) and source are credited.

\section{References}

Allen JRL (1977) Physical processes of sedimentation (Polish edition). PWN, Warszawa, $287 \mathrm{pp}$

Asprion U, Aigner T (1999) Towards realistic aquifer models: threedimensional georadar surveys of Quaternary gravel deltas (Singen Basin, SW Germany). Sed Geol 129:281-297

Bano M, Marquis G, Niviere B, Maurin JC, Cushing M (2000) Investigating alluvial and tectonic features with groundpenetrating radar and analyzing diffractions patterns. J Appl Geophys 43:33-41

Bartkowski T (1956) Z zagadnień geomorfologicznych okolicy Międzyrzecza (summary in English: Investigations on the kame landscape in the region of Miedzyrzecz). Badania Fizjograficzne nad Polską Zachodnią 3, PTPN, Poznań, $61 \mathrm{pp}$

Belina FA, Dafflon B, Tronicke J, Holliger K (2009) Enhancing the vertical resolution of surface georadar data. J Appl Geophys 68:26-35

Bersezio R, Giudici M, Mele M (2007) Combining sedimentological and geophysical data for high resolution 3-D mapping of fluvial archtectural elements in the Quaternary Po plain (Italy). Sed Geol 202:230-248

Boll J, van Rijn RPG, Weiler KW, Ewen JA, Daliparthy J, Herbert SJ, Steenhius TS (1996) Using ground-penetrating radar to detect layers in a sandy field soil. Geoderma 70:117-132

Bowling JC, Harry DL, Rodriguez AB, Zheng Ch (2007) Intergrated geophysical and geological investigation of a heterogeneous fluvial aquifer in Columbus Mississippi. J Appl Geophys 62:58 73

Bristow CS, Skelly RL, Ethridge FG (1999) Crevasse splays from the rapidly aggrading, sand bed, braided Niobrara River, Nebraska: effect of base-level rise. Sedimentology 46:1029-1047

Dynowska J (1972) Typy reżimów rzecznych w Polsce (in Polish). Zesz. Nauk. UJ CCXVIII. Prace Geogr 28:1-155

Ekes C, Hickin EJ (2001) Ground penetrating radar facies of the paraglacial Cheekye Fan, southwestern British Columbia, Canada. Sed Geol 143:199-217

Froese DG, Smith DG, Clement TD (2005) Characterizing large river history with shallow geophysics: the Middle Yukon River, Yukon Territory and Alaska. Geomorphology 67:391-406

Gay GR, Gay GH, Gay WH, Martinson HA, Meade RH, Moody JA (1998) Evolution of cutoffs across meander necks in Powder River, Montana, USA. Earth Surf Proc Land 23:651-662

Gilvear D, Winterbottom S, Sichingabula H (2000) Character of channel planform change and meander development: Luangwa river, Zambia. Earth Surf Proc Land 25:421-436

Gourry J-Ch, Vermeersch F, Garcin M, Giot D (2003) Contribution of geophysics to the study of alluvial deposits: a case study in the Val d'Avaray area of the river Loire, France. J Appl Geophys 54:35-49

Hickin AS, Kerr B, Barchyn TE, Paulen RC (2009) Groundpenetrating radar and capaticively coupled resistivity to investigate fluvial archtecture and grain-size distribution of a gravel floodplain in Northeast British Columbia, Canada. J Sediment Res 79:457-477

Hooke JM (1995) River channel adjustment to meander cutoffs on the River Bollin and River Dane, northwest England. Geomorphology 14:235-253 
Hooke JM (2007a) Spatial variability, mechanisms and propagation of change in an active meandering channel. Geomorphology $84: 277-296$

Hooke JM (2007b) Complexity, self-organization and variation in behavior in meandering rivers. Geomorphology 91:236-258

Jol HM, Smith DG (1995) Ground penetrating radar surveys of peatlands for oilfield pipelines in Canada. J Appl Geophys 34:109-123

Kostic B, Aigner T (2007) Sedimentary architecture and 3D groundpenetrating radar analysis of gravelly meandering river deposits (Neckar Valley, SW Germany). Sedimentology 54:789-808

Kostic B, Becht A, Aigner T (2005) 3-D sedimentary architecture of a Quaternary gravel delta (SW Germany): implications for hydrostratigraphy. Sed Geol 181:143-171

Krzyszkowski D (1996) Climatic control on Quaternary fluvial sedimentation in the Klaszczów Graben, central Poland. Quaternary Sci Rev 15:315-333

Leclerc RF, Hickin EJ (1997) The internal structure of scrolled floodplain deposits based on ground-penetrating radar, North Thompson River, British Columbia. Geomorphology 21:17-38

Luchi R, Hooke JM, Zolezzi G, Bertoldi W (2010) Width variations and mid-channel bar inception in meanders: River Bollin (UK). Geomorpholgy 119:1-8

Lunt IA, Bridge JS, Tye RS (2004) A quantitative, three-dimensional model of gravelly braided rivers. Sedimentology 51:377-414

MALA (2008) ProEx - professional explorer control unit. Operating Manual v. 2.0. pp 1-60

Młynarczyk Z, Słowik M (2008) Temporal variation of intensity of bed-load transport rate in the lower course of the Obra River near Miedzyrzecz (western Poland). Quaestiones Geographicae 27A (1):69-86

Neal A (2004) Ground-penetrating radar and its use in sedimentology: principles, problems and progress. Earth-Science Rev 66:261330

Nicoll TJ, Hickin EJ (2010) Planform geometry and channel migration of confined meandering rivers on the Canadian prairies. Geomorphology 116:37-47

Pazdur A, Fogtman M, Michczyński A, Pawlyta J (2003) Precision of ${ }^{14} \mathrm{C}$ dating in Gliwice Radiocarbon Laboratory. FIRI programme Geochronometria 22:27-40

Rotnicki K, Młynarczyk Z (1989) Późnovistuliańskie i holoceńskie formy i osady korytowe środkowej Prosny i ich paleohydrologiczna interpretacja (summary in English: Late Vistulian and
Holocene channel forms and deposits of the middle Prosna river and their palaeohydrological interpretation). Seria Geografia 43:1-76

Rowntree K, Dollar ESJ (1999) Vegetation controls on channel stability in the Bell River, Eastern Cape, South Africa. Earth Surf Process Landforms 24:127-134

Sandmeier KJ (2008) ReflexW Version 5.0. Windows 9x/NT/2000/ XP-program for the processing of seismic, acoustic or electromagnetic reflection, refraction and transmission data. $476 \mathrm{pp}$

Sass O, Friedmann A, Haselwanter G, Wetzel K-F (2010) Investigating thickness and internal structure of alpine mires using conventional and geophysical techniques. Catena 80:195-203

Schrott A, Sass O (2008) Application of field geophysics in geomorphology: advances and limitations exemplified by case studies. Geomorphology 93:55-73

Skelly RL, Bristow ChS, Ethridge FG (2003) Architecture of channelbelt deposits in an aggrading shallow sandbed braided river: the lower Niobrara river, northeast Nebraska. Sed Geol 158:249-270

Słowik M (2007) Procesy kształtujące koryto rzeczne na przykładzie dolnego odcinka Obry (summary in English: Processes forming river bed: the example of the lower course of the Obra river. http://www.press.amu.edu.pl/pazdziernik2007/n4.htm). Seria Geografia 76, Wydawnictwo Naukowe UAM, Poznań, 169 pp

Słowik M (2011) Changes of river bed pattern and traces of anthropogenic intervention: the example of using GPR method (the Obra River, western Poland). Appl Geogr 31:784-799

Słowik M, Sobczyński T, Młynarczyk Z (2009) Application of chromium and lead concentration changes to relative dating of floodplain deposits: laboratory and field experiments. Geochim Cosmochim Acta 73(13) Suppl: A1237

Słowik M, Sobczyński T, Młynarczyk Z (2010) Types of sedimentary environment in alluvial sediments distinguished on the basis of its chemical constitution: the example of the lower course of the Obra river (Western Poland). Environ Earth Sci 59:957-966

Starkel L, Soja R, Michczyńska DJ (2006) Past hydrological events reflected in Holocene history of Polish rivers. Catena 66:24-33

Van Heteren S, Fitzgerald DM, McKinlay PA, Buynevich PV (1998) Radar facies of paraglacial barrier systems: coastal New England, USA. Sedimentology 45:181-200

Vanderberghe J, van Overmeeren RA (1999) Ground penetrating radar images of selected fluvial deposits in the Netherlands. Sed Geol 128:245-270 